\title{
VICTORIAN IMPERIAL INFIRMITIES IN THE MOON STONE: SIGNS OF FAILURE OF EMPIRE
}

\author{
Chandra Bahadur K.C. ${ }^{*}$
}

\begin{abstract}
Edward Said has the conviction that Victorian novels are complicit to empire. They were the means through which power of British imperialism was continually reinforced and elaborated, but this research does not endorse Said's view completely. Hence, it goes beyond this conviction and reveals that the Victorian novels do not only support imperial culture; they also expose infirmities of empire.Although Victorian novels share imperial culture and its ethos as Said has shown, they also critique imperial culture. Some novelists of that time struggle to come to terms with the imperial culture. Wilkie Collins is one of them who stages counter narration of resistance to empire in The Moonstone.This veritable narrative text poses questions on the conviction that British Victorian novels are complicit to empire. It criticizes the imperial ambition of Britain and exposes the vulnerabilities of empire. The vulnerabilities are exposed with the bequeathing of the Moonstone by English Colonel Herncastle by murdering the innocent and devoted Brahmins. It is a staunch criticism on corrupt behavior of the colonizers toward material properties of colonized people. It shows that the British colonizers were in India mainly for torturing the colonizers for the sake of their selfish greed. To give justice against such vulnerability, the novelist describes a scene in the ending of the novel in which the Moonstone is restored in its original place in India.
\end{abstract}

Key Words: infirmities, imperialism, colonizers, colonized, resistance.

The Victorian novels participate in imperial culture, some of them are complicit to empire, whereas some others question it. This paper builds upon Edward Said's conviction that British Victorian novels are complicit to empire. Said says, "The durable and continually reinforced power of British imperialism was elaborated and articulated in the novel in a way not found in elsewhere" (Culture and Imperialism 87). In his view the novel of that time was powerful means to explain imperial cause of Britain. To some extent it is true because Victorian time was the high time for the flourishing of British Victorian Imperialism. But this research does not endorse Said's views completely. Hence, it goes beyond and reveals that the Victorian novels maintain an ambivalent attitude towards empire by not only supporting the empire but also questioning about imperial culture. Although Victorian novels share imperial culture and its ethosas Said has shown, theyalso critique imperial culture. Some novelists of that time struggle to come to terms with the imperial culture. Wilkie Collins is one of them who stages counter narration of resistance to empire in The Moonstone. * Associate Professor of Saraswati Multiple Campus (Humanities Faculty: English Department), Tribhuvan University,
Nepal 
By the late nineteenth century European imperial assumptions could not simply be questioned because Europe had erected confident, authoritative and self-congratulatory edifice of culture (Ashcroft and Ahluwalia 87). In actual sense it was "an integral part of the configuration of British Society, which it both reinforced and expressed" (P. J. Cain and A. G. Hopkins 61). Empire was an inherent part of Victorian life at home in England. There was constitutive impact of empire on domestic politics, society, culture and national narratives. In view of P. J Cain and A. G. Hopkins "imperialist enterprise was enfolded in a grand development strategy designed by Britain to reshape the world in her own image" (61). The Victorian culture has supported most aspects of the imperial experience. Some Victorian literary works have shown a tremendous international display of British power virtually unchecked over the entire world. They have shown the inherent superiority of Englishmen. They have affirmed the superlative nature of White civilization. It is the way of thinking that the white men are all in all; they are savior to the colonized; and the white men are for the well-being to the colonized others. But in reality the Victorian society was not only the supporter of monolithic imperial culture. Matikkala rightly puts, "This era is too often seen as characterized by monolithic imperial culture, when there actually was a rich cultural environment consisting not only of imperialism but also of various anti-imperialisms with various agenda" (2). Since imperialism was mainly meant for collaboration, this harsh side of imperialism was neglected by many of the novelists during Victorian period. But Wilkie Collins in The Moon Stone exposes this coercive quality of imperialism. In 1876 Lord Salisbury satirizes the coercive aspect of imperialism remarking "it is the nakedness of the sword on which we really rely" (quoted in Johnson 77). He means to show the negative side of imperialism.

Novels are known as the reservoirs of social, political, economic and cultural experiences. Only "few literary critics today assert that a literary text is independent of the history and culture that introduced it" (Tyson 149). Edward Said'sCulture and Imperialismhas shown how Victorian novels participated in and contributed to imperial culture.

Said's realization is that cultural texts like narratives express imperial culture of identity by dividing people as "us" and "them". These texts, mainly novels, discriminate English people as "us" and the colonial as "others." This process of "othering" is known as oriental discourse. In Said's view "The orient was almost European invention, and had been since antiquity a place of romance, exotic being, haunting memories and landscapes, remarkable experiences" (Orientalism 1). The Orient is not only outcome of imagination. "The Orient is an integral part of European material civilization and culture" (2). Orientalism, according to Said, is simply "a kind of Western projection onto andwill to govern over the Orient" (95).Said argues that even the "novelists" have accepted the basic distinction between East and West. Said confirms that "Orientalism [is] a Western style for dominating, restructuring and having authority over the orient" (3). With the help of Oriental discourse "European culture was able to manage the Orient politically, sociologically, militarily, ideologically, scientifically and imaginatively during Post Enlighten period" (93). The Orientalists and Orientalist discourse work to consolidate the imperial dominance of Europe.

The above mentioned facts show that in Said's view the British Victorian works are complicit to imperial culture. Said generalizes and universalizes about the dealing with imperial culture in literary works expressing the idea that all Victorian narrative works include imperial culture in the same way. His monolithic view asserts that the colonizers and their culture are always supported 
by colonial texts, but his this unipolar idea can be contested because the reality is that some of the Victorian imperial texts do not support British imperial experience. These works raise questions on British imperial activities and try to subvert the imperial binary system. In saying, British imperialism advocated for the "civilizing mission." It was said that the British Empire had to exist in non-Western territories because they needed British help. .Rudyard Kipling called this mission as "The White Men's Burden". But in reality British Empire was not only with the benevolent purpose, it was not also only for serving to the natives. In the name of civilizing to others, it was involved in rapacity, loot, greed, murder, dominance, plantations and slavery. Some of the Victorian narrative texts have explained such activities by questioning on the "civilizing mission". The contemporary great critics, Gayatri Spiivak and Homi K. Bhabha, also disagreed on Said's monolithic saying on colonizer-colonized relations. Spivak believes that "colonialism is effectively discursive product" (Waugh 350). She finds "heterogeneity of colonial oppression" There is not unipolar relationship between colonizer and colonized. She sees "point of rupture or contradiction within colonial representations and consciousness" (353).

Homi K. Bhabha has also focused on the way in which Said's Orientalism can be extended in colonial discourse analysis. Bhabha points "Said is an important figure in colonial discourse analysis because his work 'focused the need to quicken the half-light of Western history with the disturbing memory of its colonial texts that bear witness to the trauma that accompanies the triumphal art of Empire"" (Ashcroft and Ahluwalia 81). But Bhabha's own view is that the "colonial discourses and texts are shot through with destroying ambivalence" (Waugh 355). So it is not good to create stereotypes to the colonizers and colonized. Bhabha finds that "European attempts to replicate values in the colony, as part of the civilizing mission, were inevitably refracted and disturbed" (Waugh 356). Bhabha's basic argument is that power is always limited in its ability to determine identities and control representations. Bhabha thus criticizes Said's Orientalism thesis for portraying the effects as singular and inexorable.

As mentioned above the thesis of this paper is that although Victorian novels share imperial culture and its ethos, they also critique imperial culture. Wilkie Collin's novel The Moonstoneis one such example. It questions on Edward Said's conviction that British Victorian novels are complicit to empire. It criticizes the imperial ambition of Britain and exposes the vulnerabilities of empire. The vulnerabilities are exposed with the bequeathing of the Moonstone by English Colonel Herncastle by murdering the Brahmins. It is a staunch criticism on corrupt behavior of the colonizers toward material properties of colonized people. To give justice against such vulnerability, the novelist describes a scene in the ending of the novel in which the Moonstone is restored in its original place in India.

The novel The Moonstone (1868), set in British India, revolves round the story of loss and finding of the Moonstone, a fabulous yellow diamond having worth over twenty thousand pounds at the European markets of that time. As Patrick Brantlinger and William B. Thesing righty view that "the loss of a diamond forms the core of the entire novel" (169). The Moonstone begins as the most apparently political of Collins's novels, with its detailed account of the bloody plundering of a colonial village in India by occupying British troops and the conspiracy of vengeance that violence produces. The novel takes its title from the gem which is sacred to the Hindu god, but stolen by a British officer while sieging Serangapatam, a victory over India as the sign of expansion of British Empire. "Brought home to England, the Moonstone brings with it a curse, conspiracy, and eventually a murder" (Brantlinger and Thesing 311).The two sets of characters, 
Indians and English, and their interplay in the novel as well as description of Indian and British subjects give the reflection of British imperialism in India. The three Indians in the novel are shadowed but their presence floats all over the novel.

The novel The Moonstone begins with the description of the storming of Seringapatam by the British army under General Baird, on the fourth of May, 1799 (The Moonstone 1). In the colonial period India was thought by colonizers as land of fabulous treasures. Before the assault to Sultan's palace the British camp was full of the stories of "the treasure in jewels and gold stored up in the palace of Seringapatam" (1). Among many stories "one of the wildest of these stories is related to a yellow Diamond- a famous gem in the native annals of India" (1). The Moonstone has the superstitious power of losing and growing its "lusture with the waxing and waning of the moon" (1). It is also "a diamond devoted to the service of god" (1). The story also says that "the deity predicted certain disaster to the presumptuous mortal who laid hands on the sacred gem, and to all of his house and name who received it after him" (2). "The adventures of the Yellow Diamond began with the eleventh century of the Christian era" (2). The Mohammedan Conqueror, Mohmod of Ghizni came to India and seized the holy city of Somnauth and its treasures were stripped of. Only the Moonstone was removed by night preserved by three Brahmins to the city of Benares. It was placed in a new shrine supported by pillars of gold. On the night when the shrine was completed, Vishnu the preserver appeared to the three Brahmins and commanded that "the Moonstone should be watched, from that time forth by three Brahmins in night and day, to the end of the generations of men" (2). After many generations, during the first years of the eighteenth century, Aurungzebe, Emperor of the Moguls, commanded "havoc and rapine" among the temples, and "the Moonstone was seized by an officer of rank in army of Aurangazebe" (3). Then the Moonstone passed from one "Mohammeden hand to another," and at last, "The Diamond fell into the possession of Tippoo, Sultan of Seringapatam, who caused it to be placed as an ornament in the handle of a dagger" (3).

This fanciful story attached to the Moonstone is romanticization of the East by the West. This type of description shows that during the colonial time the real history of colonies was presented among colonizers by appropriating it. At storming in Seringapatam Tippoo is killed by British army and the British soldiers find their way into the treasury of the palace and load themselves with gold and jewels. John Herncastle usurps the Moonstone set in the dagger by murdering the three Hindu Priests disguised as Muslim Sentinels deputed to watch it. The theft of the Moonstone comes to represent the legally sanctioned robbery of India by the British government. The thieving is an abuse of imperial power; it is the personal and national responsibility in the violence of imperialism. This scene proves the vulnerability of British imperialism. In EnglishliteratureinContext Frawley rightly says:

Wilkie Collins situates his novel of 1868, The Moonstone, around a fabulous stolen from an Indian shrine. Far from presenting the British Raj as the Guardians of morality and justice, Collins finds in his detective novel the opportunity to expose the greed that he believes drives his country's imperial stance (479).

Such type of greed is exposed in the novel by John Herncastle. After killing Tippoo Sultan, he goes for his dagger in which the Moonstone had been fixed. Then he kills the three Indians who were guarding the diamond and takes the jewel in his possession. 
The reference of the Moonstone in the novel also indicates the vulnerability of empire. The fictional gem, the Moonstone, referred in the novel The Moonstone is the parallel of the Koh-iNoor diamond, acquired by the British in 1849. Later it was fitted in Queen Victoria's Crown and it was regarded as historical symbol of the conquest of India (Free 351). The Governor General of India Lord Dalhousie defeated the twelve year-old maharajah Dulip Singh of Punjab and compelled him to offer the diamond directly to the Queen, as a token of his submission (Kinsey, 394). The British Empire of the time boasted as victory over India by looting its valuables.

The Moonstone is first removed from its secret Indian shrine and subsequently relegated to the status of decorative bauble and is worn by a descendant of its thief. It is the imperial repercussion.

The Moonstone causes harm because of the vulnerability of empire by removing it from its original place i.e. from the forehead of the moon god. It was at first misused by Mugal empire, and then by British Empire. The Moonstone's theft is an expression of British colonial domination and the disappearance of the diamond from the novel is a denial of this disagreeable political truth. It suggests that the domination cannot remain in dominating situation. The diamond has indomitable quality. It shows the negative effect of empire at home. It disturbs the country house of Britain. As Franklin Blake exclaims, "When I came here from London with that horrible diamond.... I don't believe there was a happier household in England than this. Look at the household now! Scattered, disturbed- the very air of the place poisoned with mystery and suspension" (188).

The Moonstone has two faces: for the capitalist West, it is an ornament for conspicuous display. On the other hand, for the Indians it is a sacred object placed in the forehead of moon god. For the East it is a symbol of spiritual power, uniting the intellectual and emotional forces inherent in human and divine nature.

Brahmins are morally superior to the novel's English gem-hunters. It is unclear whether these Indians are related by blood to the original priests of the eighteenth century, those to whom Vishnu spoke his command. Regardless they are their successors and from a kind of family, amongst themselves as well as with their ancestors, their devotion to their religion stands in stark contrast to the blatant hypocrisy of Miss Clack and her revered Godfray Ablewhite with the exception of their smothering of the conniving Abblewhite, the Indians are not murderous in the passage. Even at Seringapatam, we hear of no Indian committing a single act of violence, we see them, rather, on the receiving end of a deathly assault.

In TheMoonstone Herncastle is a fictional character who is described as being involved in looting the jewels of Tippoo Sultan during the storming of Seringapatam. But in the real attack, too, Tippoo Sultan had been murdered cold bloodedly and his jewels, ornaments, and precious stones had been seized by the British soldiers. Different parts of his throne, his armor, swords, muskets and other curious articles are placed in British museum. General Baird's family is even now in possession of an amulet removed from the lifeless arm of the Sultan (Free 351).

Colonel Herncastle knew that the diamond caused misfortune to its owner, but he possessed it with him. "He never attempted to sell it...he never gave it away; he never even showed it to any living soul" (The Moonstone33). "He kept the diamond in flat defiance of assassination, in India. He kept the Diamond, in flat defiance of public opinion, in England" (34). Such type of emotional desire to keep diamond with him is an imperial desire of possession 
The Moonstone is the pivotal element in the novel. The stone has a long history which starts from the eleventh century facing different turbulences. Different emperors of different periods take the possession of the stone and at last in 1799, at the storming of Seringapatam, Mr. Herncastle, a British Colonel, takes the possession of the diamond treacherously by blood shedding and keeps it in his possession for many years and the stone is presented to Rachel Verinder, the niece to Colonel Herncastle, at her eighteenth birthday party as per the will of Herncastle. But the stone gets lost at the very night mysteriously, but, in reality, is stolen by Godfrey Ablewhite and put in a bank as pawn. After one year, the Moonstone is taken by the three Indian Brahmins by killing Godfrey Ablewhite and is taken back to India. In the city of Somnauth, India, a great religious ceremony is organized "in honour of the god of the Moon" (520). Then the Moonstone is restored in the forehead of the Moon God.

This process of restoration of the Moonstone in its original place in the religious city of India indicates the resistance to imperialism. The extraneous effort of the three Brahmins to take back the Moonstone from England to India represents the untiring endeavor to resist imperialism. This episode of the restoration of the Moonstone conveys the message that the process of imperialism and resistance to it go hand in hand. The Moonstone symbolizes the faith of Indian people, and their efforts to recapture it is their staunch belief on their faith. The storming at Seringapatam is the attack on the culture of Indian people. Though in disguised form the three Brahmins resist it and become able to get it back in its previous position. This restoration process of the Moonstone indicates the vulnerability of British Empire. The British colonies were hitting on the cherished part of Indian people.

In this way the Victorian novel The Moonstonedescribes the infirmities of empire. Ittries to justify the vulnerable behaviours shown by the imperialists. It claims that British imperialism was not only oriented by civilizing mission. Instead, it was also full of rapacity, greed and treachery. In the novel such behavior is mainly seen by Colonel Herncastle whose greed of the precious diamond leads him to kill innocent Brahmins. The restoration of the Moonstone by the great effort of the three Brahmins at its original place in India indicates Indian's undaunted resistance to imperialism. To come to conclusion, all the Victorian novels are not complicit to imperialism as claimed by Edward Said. Some of them are also criticizing the process of colonization. By emphasizing the vulnerabilities of empire, they also foreshadow the failure of imperialism. 


\section{Works Cited}

Ashcroft, Bill, NGareth Griffiths and Helen Tiffin. Post-Colonial Studies:The Key Concepts. Routledge, 2000.

Ashcroft, Bill and Pal Ahluwalla. Edward Said. Routledge, 2001.

Brantlinger, Patrick \& William B. Thesing. A Companion to The Victorian Novel.Blackwell Publishing, 2002.

Cain, P. J. \& A. G. Hopkins. British Imperialism 1688-2015. Routledge, 2016.

Collins, Wilkie. The Moonstone. Oxford University Press, 1972.

Free, Melissa P. “'Dirty Linen': Legacies of Empire in Wilkie Collins's The Moonstone.” Texas Studies in Literature and Language. Vol. 4. (Winter 2006). 340-371. University of Texas Press.

Johnson, Robert. British Imperialism. Palgrave, Macmillan, 2003.

Matikkala, Maria. Empire and Imperial Ambition: Liberty, Englishness and Anti-Imperialism in Late Victorian Britain. I. B. Tauris \& Co. Ltd., 2011.

O'Gorman, Fracis, ed. A Concise Companion to the Victorian Novel. Blackwell Publishing, 2005.

Poplawski, Paul, ed. English Literature in Context. Cambridge University Press, 2008.

Said, Edward W. CultureandImperialism. Vintage, 1993.

-Orientalism. Penguin, 1978.

Tyson, Lois. Critical Theory Today. Routledge, 2006.

Waugh, Patricia, ed. Literary Theory and Criticism: An Oxford Guide.

Oxford University Press, 2006. 